\title{
Comparison between the In Situ Tests' Data and Empirical Equations for Estimation of Deformation Modulus of Rock Mass
}

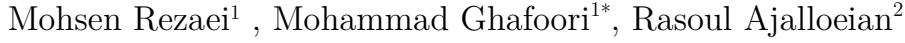 \\ ${ }^{1}$ Geology Departement, Ferdowsi University of Mashhad, Iran \\ ${ }^{2}$ Geology Departement, Isfahan University, Iran \\ Email: ghafoori@um.ac.ir
}

\begin{abstract}
The rock mass deformation modulus $\left(\mathrm{E}_{\mathrm{rm}}\right)$ is a significant input parameter in any analysis of rock mass behavior. To find $\mathrm{E}_{\mathrm{rm}}$, both in situ tests as well as indirect methods can be utilized. The in situ tests are not only time consuming and expensive, but also the reliability of these tests' results is sometimes questionable. Therefore, several researchers have proposed empirical equations for estimating $\mathrm{E}_{\mathrm{rm}}$ on the basis of rock mass classification systems or geomechanical properties of rock mass. In this paper, these equations are reviewed based upon data obtained from a large number of in situ tests performed in Bakhtiari and Khersan II dam sites- in southwest parts of Iran. Among the equations related to rock mass rating (RMR), the ones provided by Hoek-2002 and Shen-2012 have presented the best predictions. It appears that Hoek-2002 equations have provided more acceptable results than other equations correlated to geological strength index (GSI).
\end{abstract}

Keywords: Rock mass deformation modulus, in situ test, indirect methods, Bakhtiari dam, Khersan II dam.

\section{Introduction}

Measuring the rock mass deformation modulus $\left(\mathrm{E}_{\mathrm{rm}}\right)$ is not often an easy task to do. It has been considered as the most typical parameter illustrating the pre-failure mechanical behaviour of rock mass. Intact rock elastic modulus is measured by uniaxial compression strength test in laboratories. The existence of discontinuities however, makes a great difference between the mechanical properties of rock mass and intact rock. $\mathrm{E}_{\mathrm{rm}}$ is a basic input data for most rock engineering projects including tunnelling, support designing, foundation designing, etc. For these purposes, it is necessary to obtain this parameter before starting numerical modelling. $\mathrm{E}_{\mathrm{rm}}$ can be evaluated by in situ tests. These tests can be applied in different methods such as plate loading, plate jacking, radial jacking, flat jacking, and cable jacking. However, related costs are high and performing procedures are difficult. At the preliminary design stage, there are several empirical equations for obtaining $\mathrm{E}_{\mathrm{rm}}$, since at that point it is not reasonable to do in situ tests, due to the difficulties encountered when performing these tests. Several authors have proposed these relationships for estimating the value of an isotropic rock mass deformation modulus on the basis of rock mass classification schemes such as Rock Mass Rating (RMR) [1-7], Tunnelling Quality Index (Q) [8, 9], Geological Strength Index (GSI) [6, 10-12], and Rock Mass Index (RMi) [13]. Furthermore, other authors have proposed equations relating $\mathrm{E}_{\mathrm{rm}}$ to Rock Quality Designation (RQD) and elastic modulus of intact rock [14](Table 1$)$.

In this paper, $\mathrm{E}_{\mathrm{rm}}$ of Bakhtiari and Khersan II dam sites are measured by plate jacking tests. These data are compared with the empirical equations represented in Table 1. As shown in figure 1 below, Bakhtiari dam site is located in the southwest of Iran, almost $70 \mathrm{~km}$ northeast of Andimeshk city (Khuzestan province) and $65 \mathrm{~km}$ southwest of Dorud city (Lorestan province). Khersan II dam site is located in southwest of Iran, $60 \mathrm{~km}$ southwest of Lordegan city in Chaharmahal and Bakhtiari province. 
Table 1. Empirical equations used for estimation of $\mathrm{E}_{\mathrm{rm}}$ in this study.

\begin{tabular}{|c|c|c|}
\hline Author & Empirical Equation & Limitation \\
\hline Zhang $[14]$ & $\mathrm{E}_{m} / \mathrm{E}_{r}=10^{0.0186^{*} R Q D-1.91} \quad x+y=z$ & \\
\hline Hoek et al. [6] & $\mathrm{E}_{m}=\sqrt{\frac{\sigma_{c}}{100}} \times 10\left(\frac{R M B-10}{40}\right)$ & \\
\hline Sonmez et al. [7] & $\mathrm{E}_{m}=\mathrm{E}_{i} 10^{[(R M R-100)(100-R M R) / 4000 \exp (-R M R / 100)]}$ & \\
\hline Nejati et al. [1] & $\begin{array}{l}\mathrm{E}_{m}=-7.192+0.06469 U C S+0.20418 R Q D+0.30974 J S+ \\
0.38384 J C+0.1716 G W\end{array}$ & \\
\hline Barton [9] & $\mathrm{E}_{m}=10 Q_{c}^{1 / a} \quad Q_{c}=Q \sigma_{c i} / 100$ & \\
\hline Palmstrom[13] & $\mathrm{E}_{m}=5.6 R M i^{0375}$ & $\mathrm{RMi}<0.1$ \\
\hline \multirow{2}{*}{ Hoek et al. [6] } & $\mathrm{E}_{m}=\left(1-\frac{D}{2}\right) \sqrt{\sigma_{c i} / 100} \times 10\left(\frac{G S I-10}{40}\right)$ & $\mathrm{UCS}<100 \mathrm{MPa}$ \\
\hline & $\mathrm{E}_{m}=\left(1-\frac{D}{2}\right) \times 10\left(\frac{G S I-10}{40}\right)$ & $\mathrm{UCS}>100 \mathrm{MPa}$ \\
\hline Kayabasi et al.[15] & $\mathrm{E}_{m}=0.135\left[\frac{\mathrm{E}_{i}\left(1+\frac{R Q D}{100}\right)}{W D}\right]^{1.1911}$ & \\
\hline $\begin{array}{l}\text { Gokceoglu et } \\
\text { al.[16] }\end{array}$ & $\mathrm{E}_{m}=0.001\left[\frac{\left(\mathrm{E}_{i} / U C S\right)\left(1+\frac{R Q D}{100}\right)}{W D}\right]^{1.5528}$ & \\
\hline $\begin{array}{l}\text { Hoek and } \\
\text { Diederichs[10] }\end{array}$ & $\mathrm{E}_{m}=\mathrm{E}_{i}\left(0.02+\frac{1-D / 2}{1+e\left(\frac{60+15 D-G S I}{11}\right)}\right)$ & \\
\hline Sonmez et al.[11] & $\mathrm{E}_{m}=\mathrm{E}_{i}\left(S^{a}\right)^{0.4} \quad s=\exp \left(\frac{G S I-100}{9}\right) \quad a=\frac{1}{2}+\frac{1}{6} \exp \left(-\frac{G S I}{15}\right)-\exp \left(-\frac{20}{3}\right)$ & \\
\hline Carvalho [12] & $\mathrm{E}_{m}=\mathrm{E}_{i} s^{1 / 4} s=\exp \left(\frac{G S I-100}{9}\right)$ & \\
\hline Shen et al. [17] & $\begin{array}{l}\mathrm{E}_{m}=110 e^{-\left(\frac{R M R-110}{37}\right)^{2}} \\
\mathrm{E}_{m}=1.14 E_{i} e^{-\left(\frac{R M R-116}{41}\right)^{2}}\end{array}$ & \\
\hline Beiki et al. [18] & $\begin{array}{l}\mathrm{E}_{m}=\tan \left(\sqrt{1.56+(\operatorname{In}(G S I))^{2}}\right)^{2} \sqrt{U C S} \\
\mathrm{E}_{m}=\tan (\operatorname{In}(G S I)) \log (U C S)^{2} \sqrt{R Q D}\end{array}$ & \\
\hline & $\mathrm{E}_{m}=10^{\frac{R M R-10}{40}}$ & $\mathrm{RMR} \leqslant 56$ \\
\hline $\begin{array}{l}\text { Lowson\& } \\
\text { Bieniawski }[19]\end{array}$ & $\mathrm{E}_{m}=14+\left(\mathrm{E}_{j}-14\right)\left[1-\left(\frac{100-R M R}{44}\right)^{\frac{R M R-10}{70}}\right]$ & $\mathrm{RMR}>56$ \\
\hline
\end{tabular}




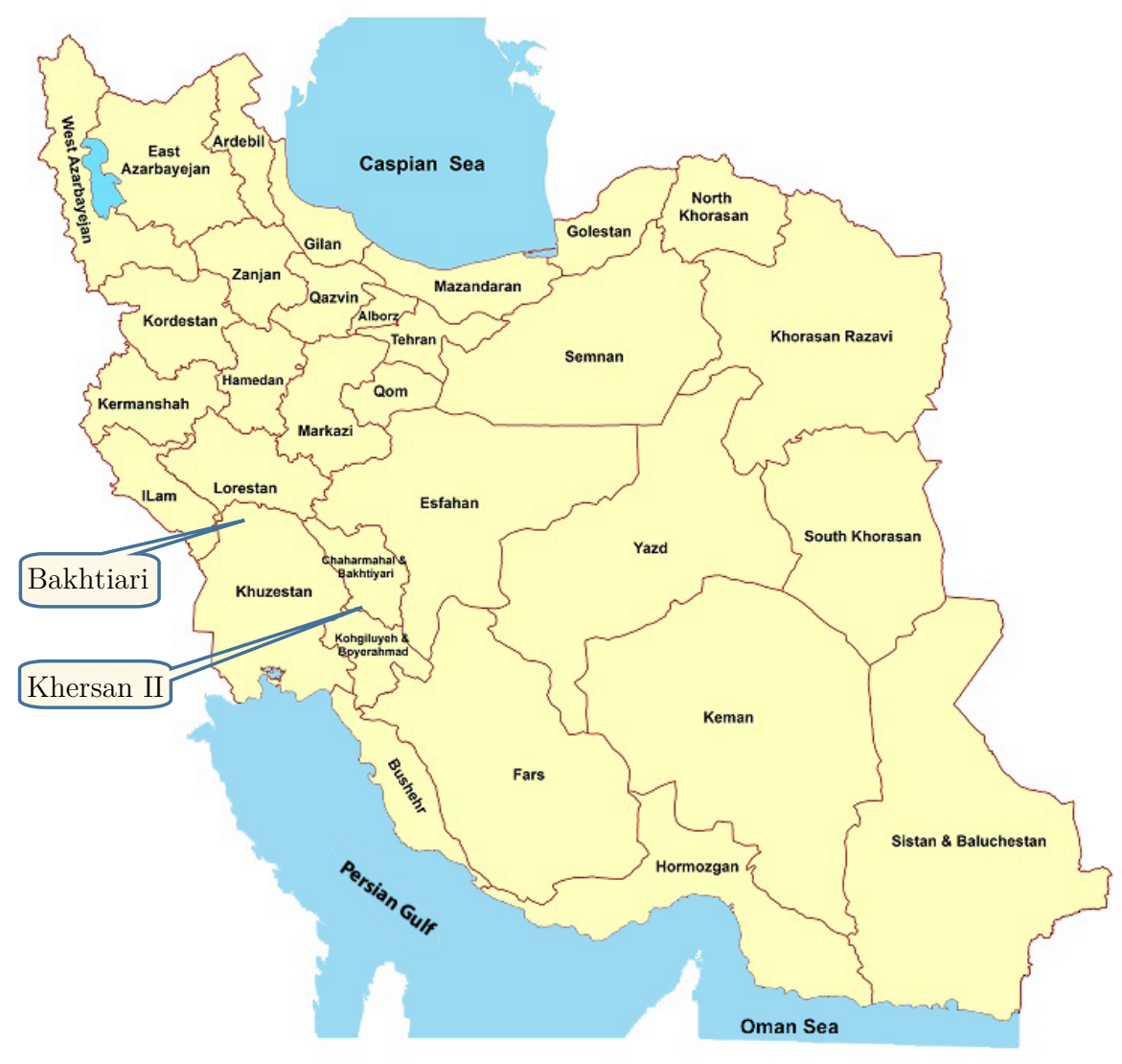

Figure 1. Location of study areas in Iran.

\section{Geology of Study Areas}

Rock masses in Bakhtiari dam site consist of limestone and marl limestone that contain dolomite and nodules of siliceous limestone, which is named as Sarvak formation. At the study area, Sarvak formation has been divided into 7 units: Sv1 to Sv7. Units Sv2 to Sv6 have outcrops in the dam site. Sv2 unit consists of marl limestone with thin inter-bedding of marl and shale. Sv3 unit consists of an intercalation of marl and siliceous limestone. Some parts of marl and siliceous limestone in Sv3 unit are folded. These heterogeneous parts are named as kink band zone (KB). Sv4 includes medium to thick bedded limestone with siliceous nodules. Sv5 consists of thick to very thick bedded nodular limestone. Sv6 is made of thick bedded and marl limestone with thin marl intercalations.

The outcropped rock masses at Khersan II dam site consist of limestone, marl limestone, and a type of marl named Asmari formation (As). Asmari formation at the study area has been divided into 3 units as upper, middle, and lower Asmari formation. The upper Asmari rocks retrieved from the dam site also include limestone. Several core samples were chosen from drilled boreholes in different rock units at each dam site for laboratory

\section{$3 \quad$ Intact Rock Properties}

Several core samples have been taken from drilled boreholes in different rock units at each dam site for laboratory testing. Subsequently, uniaxial compression tests were performed to obtain UCS and E of the intact rock (UCS and $\mathrm{E}_{\mathrm{i}}$ ). The results are summarized in Table 2. 
Table 2. Summary of study areas intact rock properties.

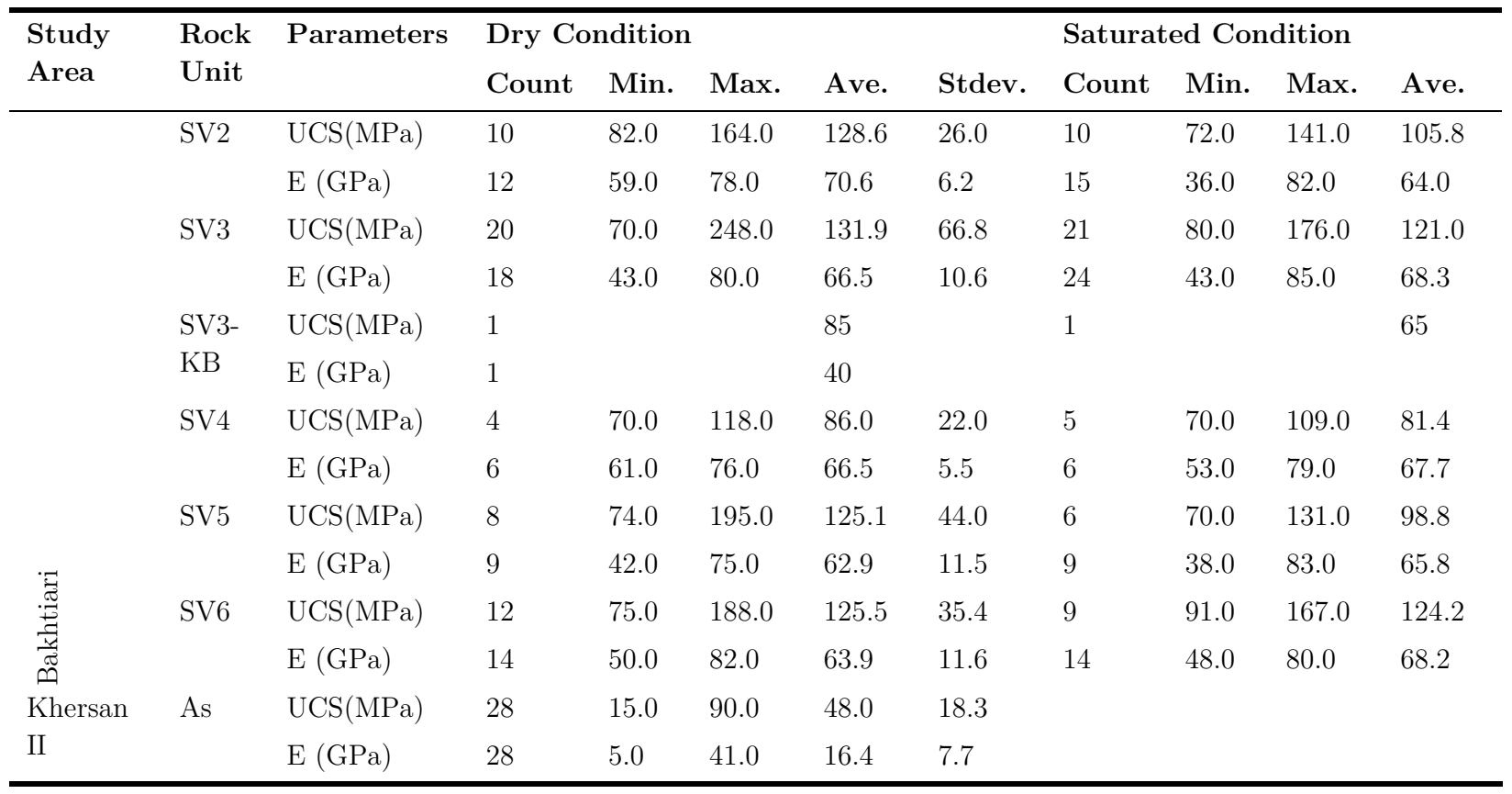

As shown in Table 2, both $\mathrm{UCS}_{\mathrm{i}}$ and $\mathrm{E}_{\mathrm{i}}$ at Bakhtiari dam site are significantly greater than Khersan II dam site. However, due to the presence of several signs of damage in the specimens, the reliability of measured values of $E_{i}$ is questionable. The specimen damage has greater effect on $E_{i}$ than $\mathrm{UCS}_{\mathrm{i}}$. Of course the intact rock strength, if available, is considered a more reliable measure. Moreover, the relative effect of damage is greater for jointed rock masses with GSI $<80$ [10]. This is consistent with the results of Palmstrom and Singh who found that the measured modulus for TBM driven tunnels was 2-3 times greater than blasted tunnels excavated in same rock masses for GSI 50-70 [20].

\section{$4 \quad$ Plate Jacking Test}

Plate jacking tests were carried out using rigid loading plates with diameters of 650 and $915 \mathrm{~mm}$ at Bakhtiari dam site, and a diameter of $1000 \mathrm{~mm}$ at Khersan II dam site. During plate jacking tests, two opposite areas in the test galleries were loaded together using rigid loading plates by means of hydraulic pump system (see figure 2). The rock displacements were measured using multiple position borehole extensometers which were fixed inside the boreholes that were drilled in the center of each loading area. In each borehole, the deeper extensometer (positioned at the end of borehole at depth more than $6 \mathrm{~m}$ ) was used as a fixed point. The stress-displacement curves for 5 other extensometers are illustrated in figure 3 for one of the tests. 


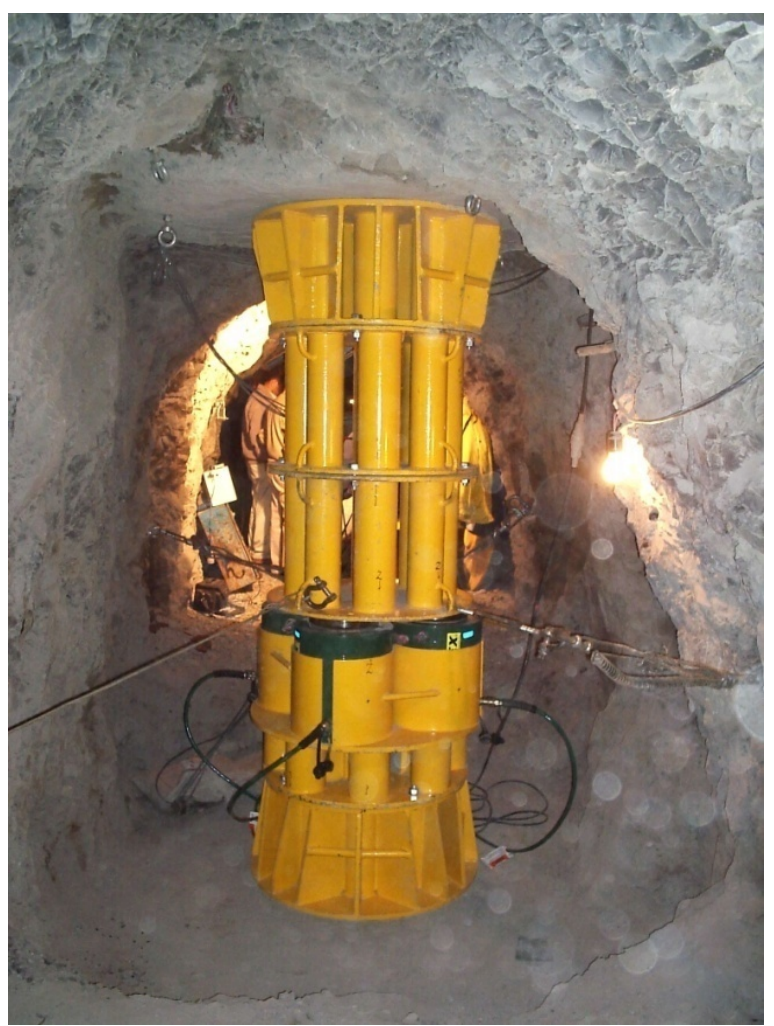

Figure 2. Plate jacking test operation.

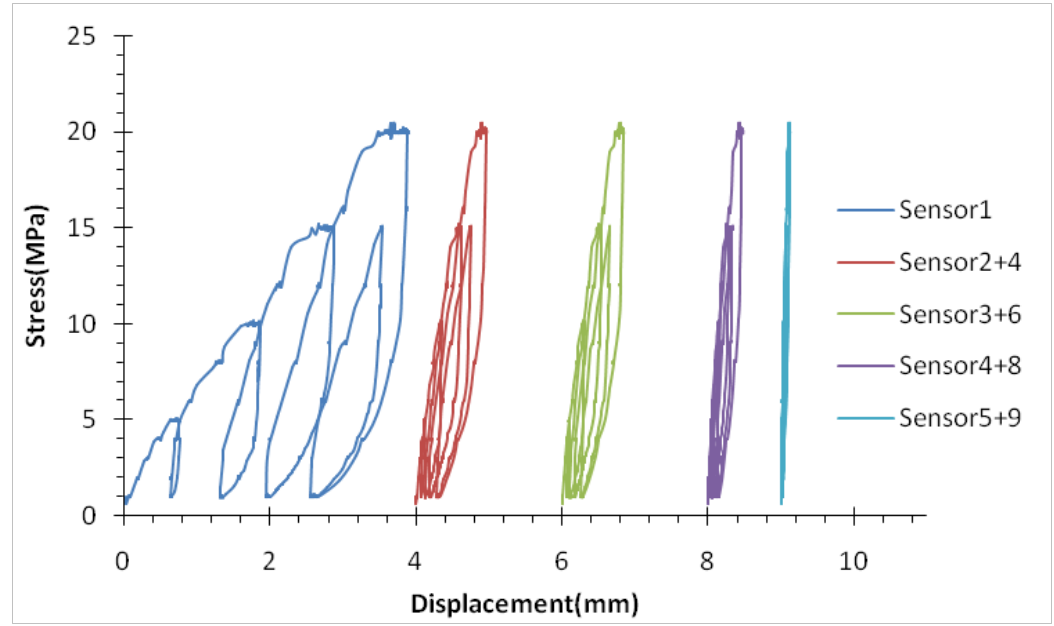

Figure 3. Stress-displacement curves which are recorded in multi position extensometers inside the drilled borehole in the test area.

Plate jacking tests are usually carried out in 5 loading and unloading cycles [21]. A typical stressdisplacement curve along with graphical definitions of peak to peak modulus of deformation (Dpp) [22], and modulus of elasticity (E) is represented in figure 4. 


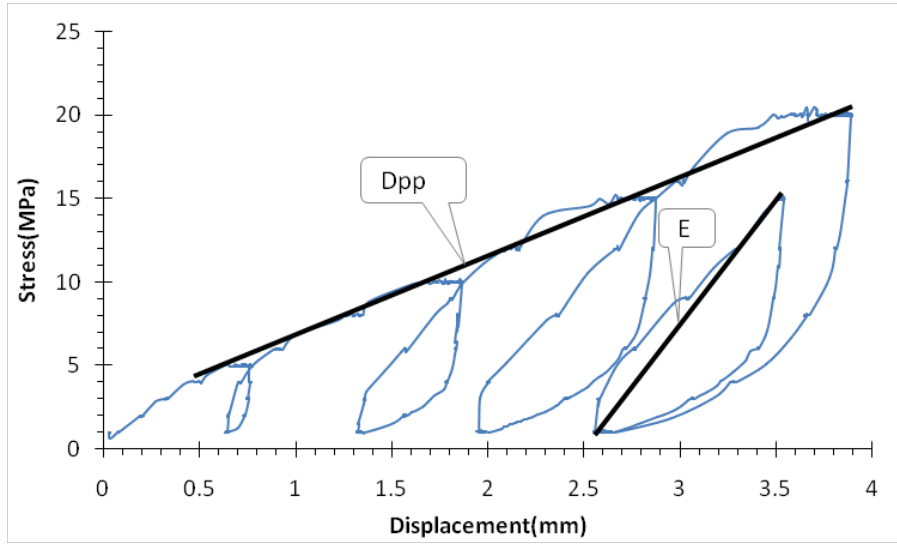

Figure 4.Typical loading and unloading cycles in PLT and definitions of E and Dpp.

According to ASTM [22] in rigid plate tests, basic formula for calculating $\mathrm{E}_{\mathrm{rm}}$ is the following:

$$
E_{m}=\frac{(1+v) P}{2 \pi W_{Z} R}[2-2 v] \arcsin \left(\frac{R}{\left(R^{2}+Z^{2}\right)^{0.5}}+\frac{R Z}{R^{2}+Z^{2}}\right)
$$

where $\mathrm{E}_{\mathrm{m}}$ is deformation modulus of rock mass $(\mathrm{GPa}), \mathrm{P}$ is total load on the loading plate $(\mathrm{KN}), \mathrm{R}$ is the radius of loading plate $(\mathrm{mm}), \mathrm{Z}$ is the depth of measurement point $(\mathrm{mm}), \mathrm{Wz}$ is the displacement in each depth $(\mathrm{mm})$, and $v$ is the Poisson ratio of the rock mass. Due to the insignificant effect of Poisson's ratio within the interval of $0.1-0.35$ on $\mathrm{E}_{\mathrm{rm}}[20]$, a Poisson's ratio equal to 0.3 was used for the entire rock mass in concordance with the petite seismic tests.

Several plate jacking tests (Table 3) in vertical and horizontal directions were carried out at Khersan II and Bakhtiari dam sites. Tests were examined, and invalid data were excluded from the study. Summary of these test results is presented in Table 3.

Table 3. Summary of in situ test results.

\begin{tabular}{lllllllllll}
\hline Study area & & Khersan II & \multicolumn{2}{l}{ Bakhtiari } & & & & Total Data \\
\cline { 1 - 7 } Rock unit & & As & Sv2 & Sv3 & Sv3-Kb & Sv4 & Sv5 & Sv6 & \\
Count & & 28 & 6 & 55 & 6 & 10 & 4 & 8 & 117 \\
Dpp (GPa) & Ave. & 24.2 & 12.3 & 8.7 & 4.2 & 4.6 & 22.4 & 23.7 & 13.5 \\
& Min. & 5.6 & 5.5 & 1.3 & 1.6 & 0.9 & 20.7 & 15.9 & 0.9 \\
& Max. & 45.0 & 20.2 & 29.8 & 7.4 & 9.1 & 23.8 & 33.1 & 45.0 \\
& Stdev. & 13.0 & 5.2 & 6.6 & 2.3 & 2.7 & 1.6 & 5.8 & 11.1 \\
\hline
\end{tabular}

\section{Geometry and Properties of Discontinuities}

The rock mass of both study areas were intersected by two main discontinuity systems including bedding planes and joints which affect the rock masses properties. The bedding plane and the joint characteristics such as dip, dip direction, aperture, persistency, spacing, infilling, and roughness were recorded for galleries and boreholes to evaluate rock masses classification indices.

\section{Rock Mass Classification}

There are several rock mass classification systems such as RQD[23] RMR[24], Q[25], RMi[13], and GSI[26-31] that are used for various engineering design and analysis. All of the classification systems are designed based on empirical equations between rock mass characteristics and engineering applications, such as tunnels, slopes, foundations, etc. In this study, the rock mass of each in situ test location were 
classified using the above mentioned systems. The results are summarized in Table 4. Subsequently, a simple regression analysis was performed between rock mass classification systems and in situ tests data.

Table 4. Summary of rock masses classification in the study areas

\begin{tabular}{lllllll}
\hline & & RQD & Q & RMR-89 & GSI-2013 & RMi \\
\hline \multirow{5}{*}{ Khersan II } & Ave. & 78.5 & 30.4 & 62.4 & 68.3 & 7.9 \\
& Min. & 38.0 & 5.8 & 34.0 & 40.0 & 0.5 \\
& Max. & 100.0 & 66.7 & 84.0 & 83.0 & 24.0 \\
& Stdev. & 17.8 & 17.3 & 13.1 & 12.5 & 6.5 \\
& Ave. & 66.1 & 5.9 & 45.5 & 57.0 & 3.7 \\
Bakhtiari & Min. & 17.0 & 0.6 & 22.0 & 28.0 & 0.2 \\
& Max. & 99.0 & 17.8 & 65.0 & 78.0 & 19.5 \\
& Stdev. & 19.4 & 4.0 & 10.7 & 11.1 & 4.0 \\
& Ave. & 69.1 & 11.8 & 49.5 & 59.7 & 4.7 \\
& Min. & 17.0 & 0.6 & 22.0 & 28.0 & 0.2 \\
& Max. & 100.0 & 66.7 & 84.0 & 83.0 & 24.0 \\
& Stdev. & 19.7 & 13.9 & 13.4 & 12.4 & 5.0 \\
\hline
\end{tabular}

As demonstrated in Table 5 and figure 5 below, the R-squared value of correlation between RQD and in situ data is lower than other classification systems which have approximately similar R-squared values. Considering both sites, the RMR system shows the best results for the entire data compared to the rest.

Table 5. Summary of simple regression between measured Erm and rock mass classification.

\begin{tabular}{|c|c|c|c|c|c|c|}
\hline \multirow{2}{*}{ classification system } & \multicolumn{2}{|l|}{ Bakhtiari } & \multicolumn{2}{|l|}{ Khersan II } & \multicolumn{2}{|l|}{ All Data } \\
\hline & Relationship & $\mathrm{R}^{2}$ & Relationship & $\mathrm{R}^{2}$ & Relationship & $\mathrm{R}^{2}$ \\
\hline RQD & $\mathrm{Em}=1.234 \mathrm{e}^{0.026 \mathrm{RQD}}$ & 0.35 & $E m=3.322 \mathrm{e}^{0.023 R Q D}$ & 0.380 & $\mathrm{Em}=1.157 \mathrm{e}^{0.030 \mathrm{RQD}}$ & 0.40 \\
\hline $\mathrm{Q}$ & $\mathrm{Em}=1.797 \mathrm{Q}^{0.905}$ & 0.57 & $\mathrm{Em}=1.639 \mathrm{Q}^{0.780}$ & 0.693 & $\mathrm{Em}=2.180 \mathrm{Q}^{0.744}$ & 0.66 \\
\hline RMR- 89 & $\mathrm{Em}=0.326 \mathrm{e}^{0.063 \mathrm{RMR}}$ & 0.62 & $\mathrm{Em}=1.271 \mathrm{e}^{0.044 \mathrm{RMR}}$ & 0.684 & $\mathrm{Em}=0.368 \mathrm{e}^{0.062 \mathrm{RMR}}$ & 0.69 \\
\hline GSI- 2013 & $\mathrm{Em}=0.237 \mathrm{e}^{0.059 \mathrm{GSI}}$ & 0.58 & $\mathrm{Em}=1.059 \mathrm{e}^{0.043 \mathrm{GSI}}$ & 0.658 & $\mathrm{Em}=0.247 \mathrm{e}^{0.060 \mathrm{GSI}}$ & 0.64 \\
\hline RMi & $\mathrm{Em}=3.942 \mathrm{RMi}^{0.703}$ & 0.66 & $\mathrm{Em}=8.407 \mathrm{RMi}^{0.543}$ & 0.672 & $\mathrm{Em}=4.316 \mathrm{RMi}^{0.731}$ & 0.68 \\
\hline
\end{tabular}

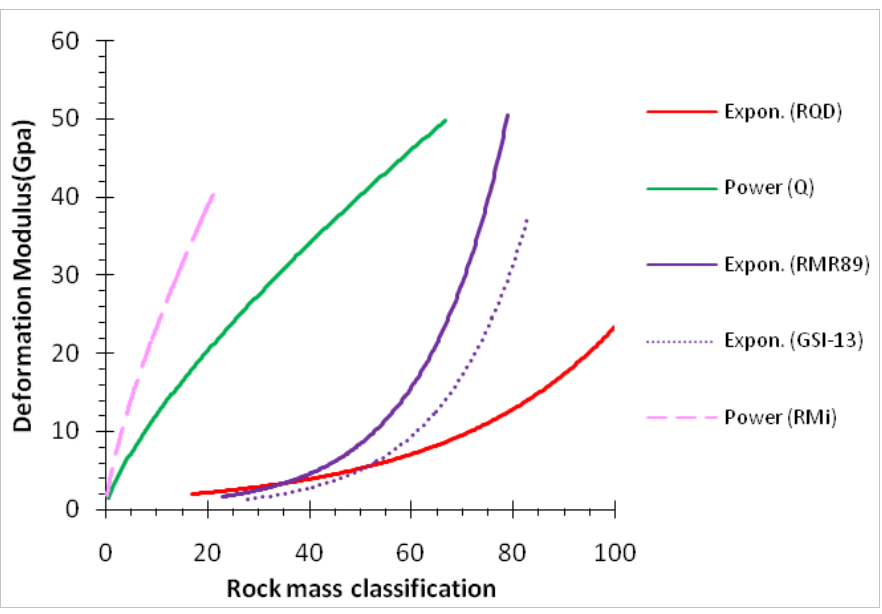

Figure 5. Proposed relationship (best fit) between measured $\mathrm{E}_{\mathrm{rm}}$ and rock mass classification of projects data. 


\section{$7 \quad$ Prediction of Erm Using Empirical Equations}

In this stage of study, $\mathrm{E}_{\mathrm{rm}}$ at in situ tests locations were estimated by empirical equations which were proposed by several authors mentioned in Table 1. The results of predictions are presented in figures 6 and 7. Given the limitations of the mentioned equations, it is not possible to use all these equations for all in situ test locations. However, most of the equations were usable for our test locations.

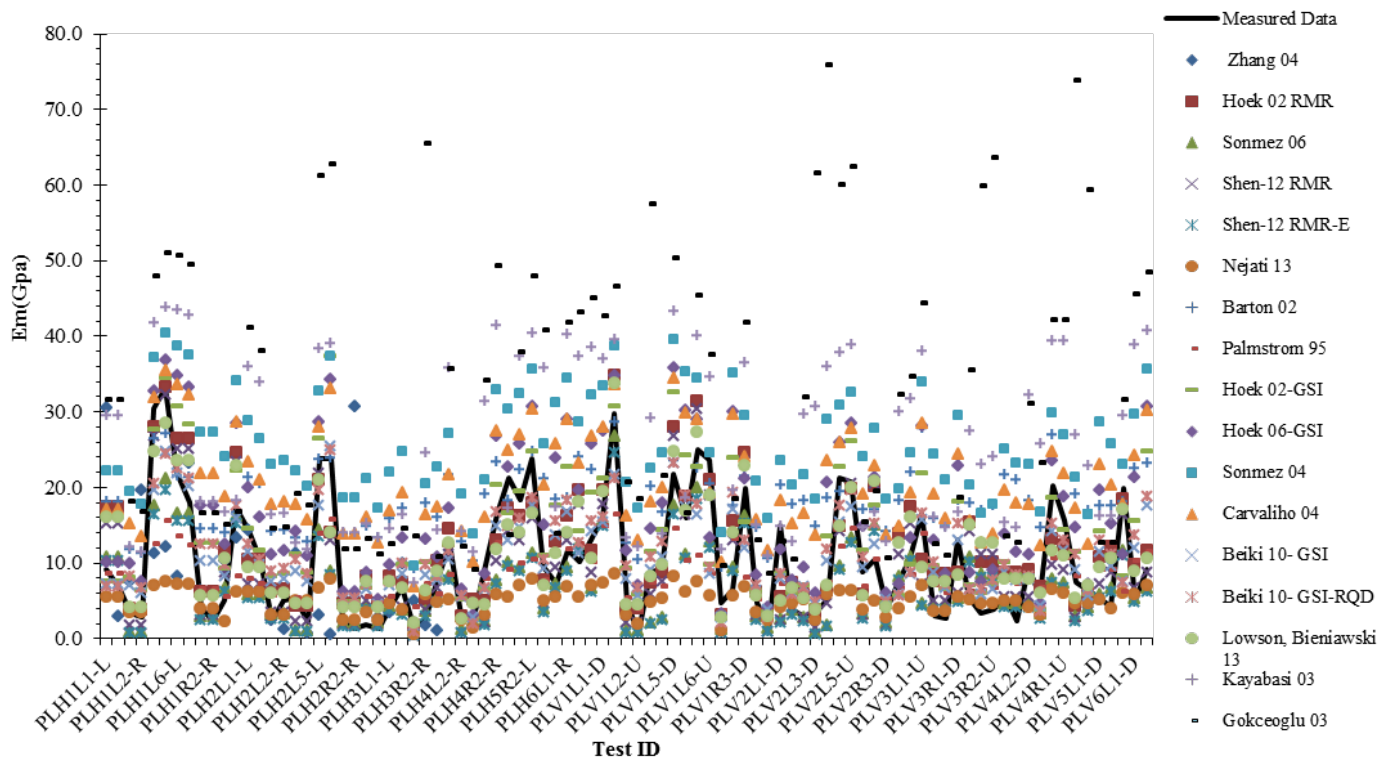

Figure 6. Predicted results of $\mathrm{E}_{\mathrm{rm}}$ based on different empirical equations.

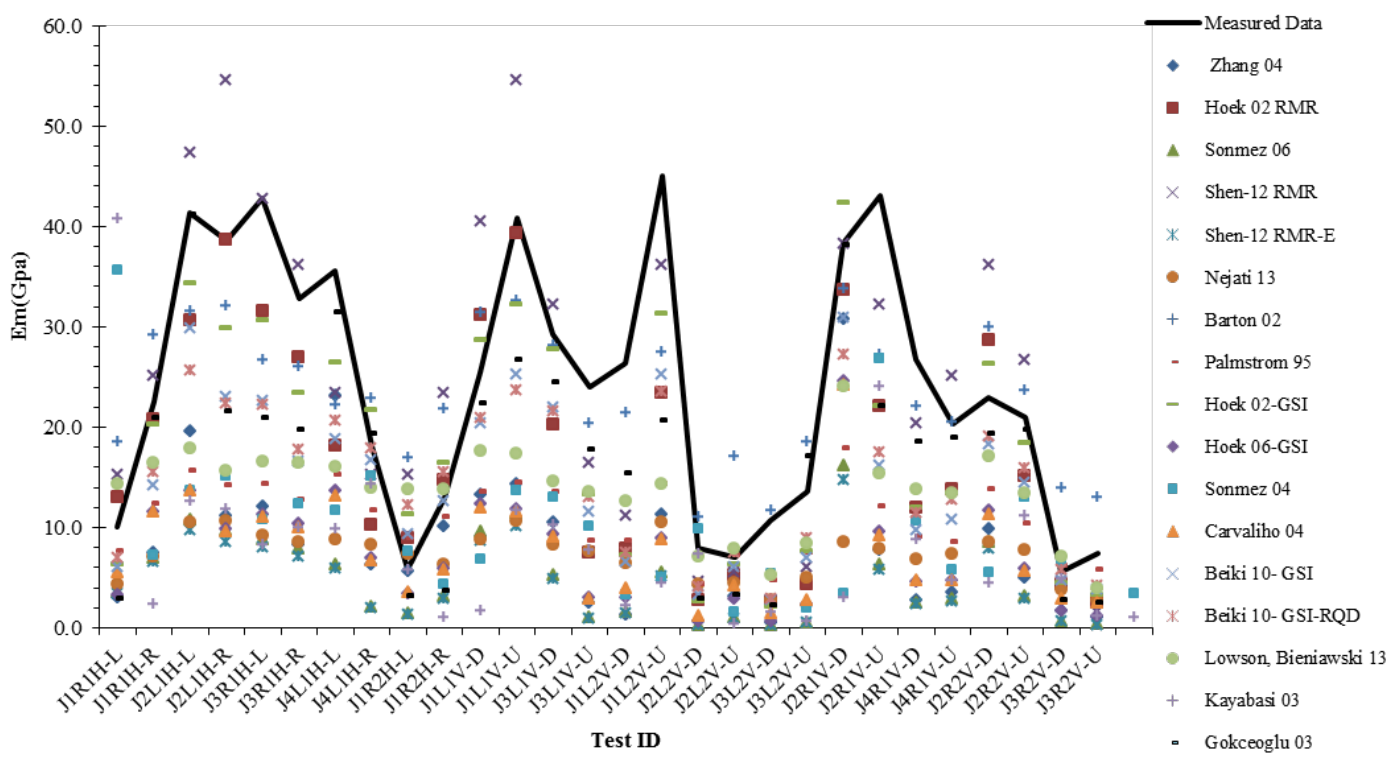

Figure 7. Predicted results of $\mathrm{E}_{\mathrm{rm}}$ based on different empirical equations. 


\section{Comparison Between In Situ Tests Results and Indirect Estimation of $\mathrm{E}_{\mathrm{rm}}$}

Finally the measured values of $\mathrm{E}_{\mathrm{rm}}$ by in situ tests and the estimated values by different equations at Bakhtiari and Khersan II dam sites were compared. The results are shown in figures 8, 9, and 10 and Table 6 .

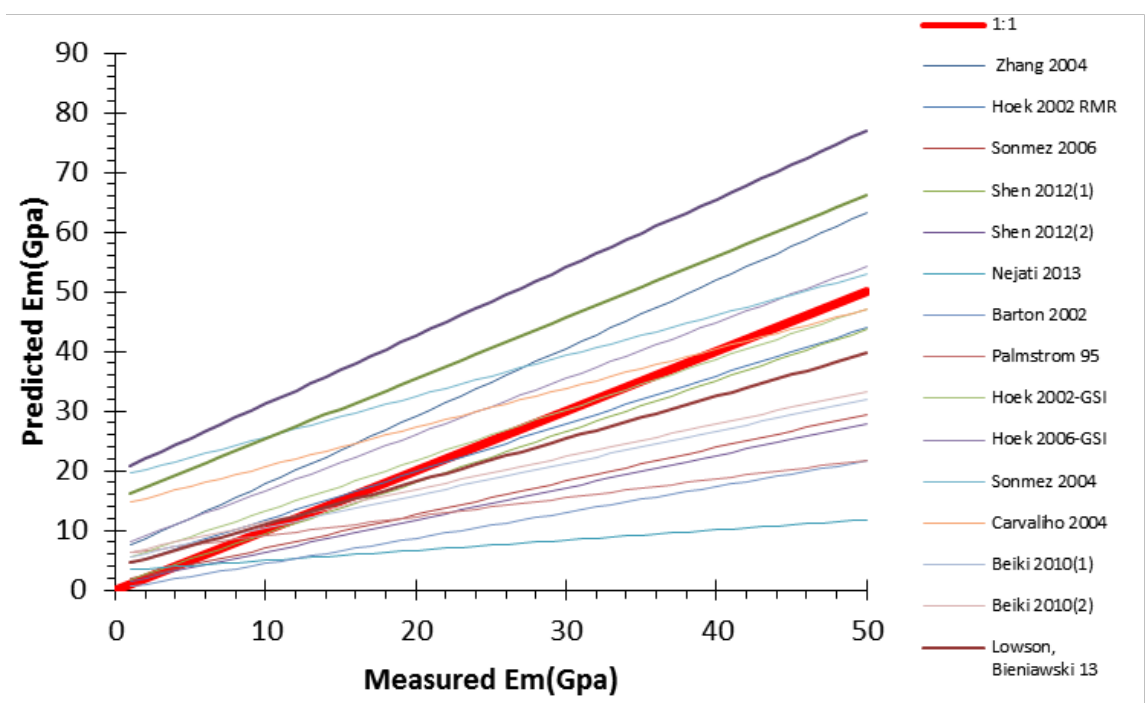

Figure 8. Comparison between measured and predicted $\mathrm{E}_{\mathrm{rm}}$ at Bakhtiari dam site using several empirical equations.

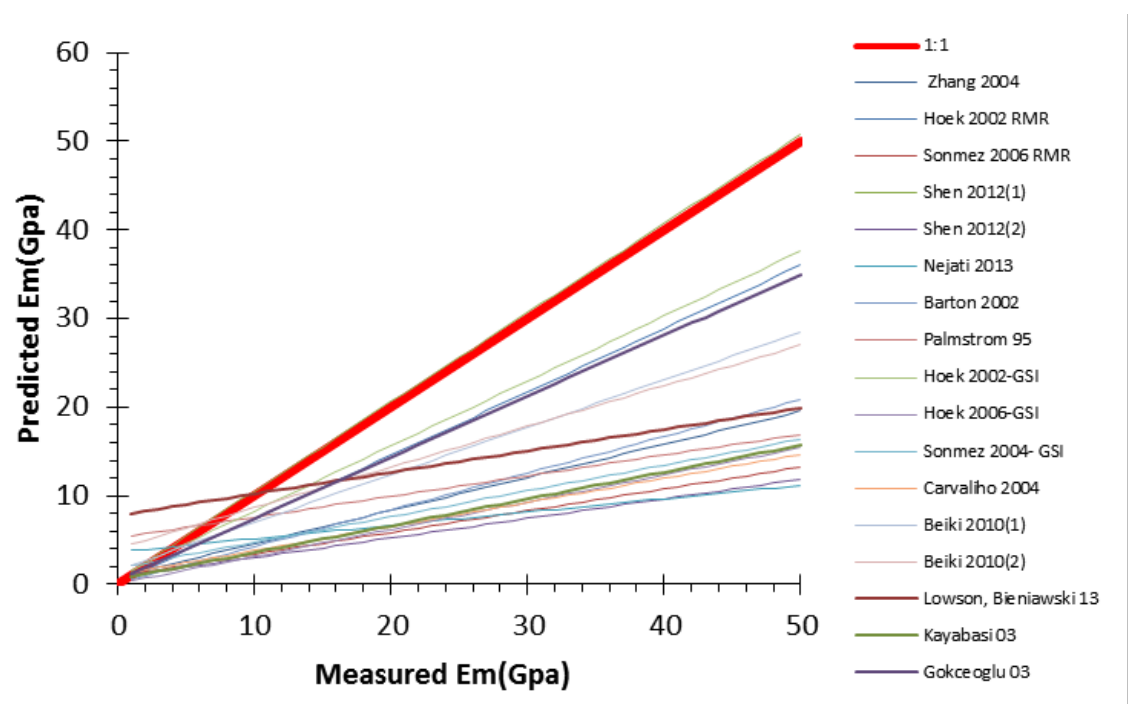

Figure 9. Comparison between measured and predicted $\mathrm{E}_{\mathrm{rm}}$ at Khersan II dam site using several empirical equations. 


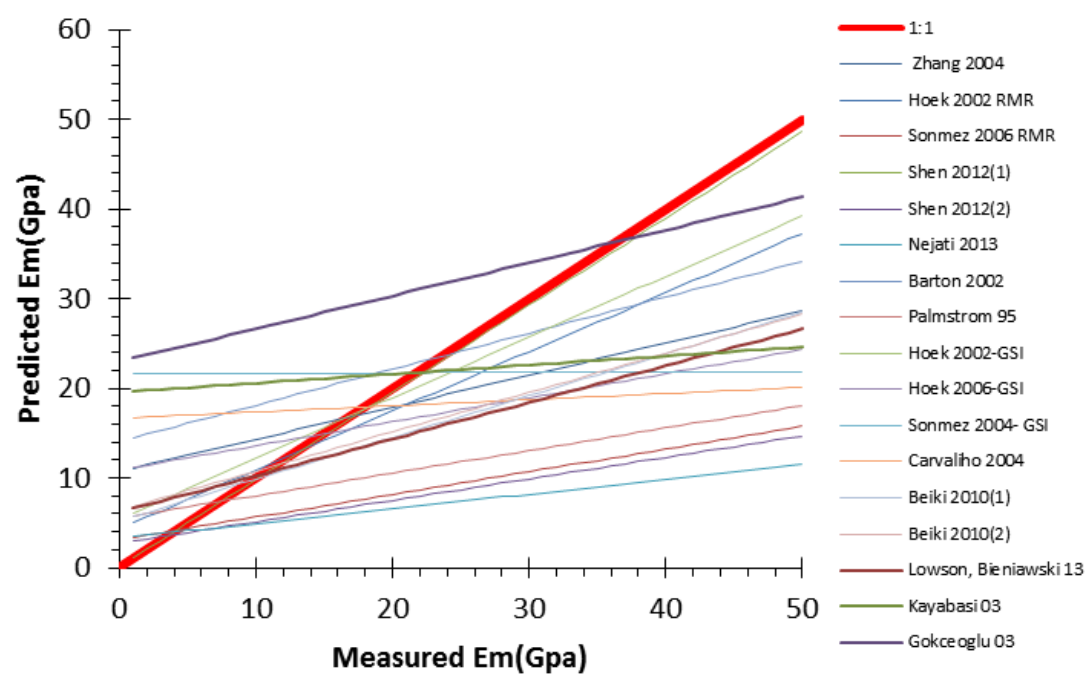

Figure 10. Comparison between measured and predicted $\mathrm{E}_{\mathrm{rm}}$ using several empirical equations(all data).

Table 6. R-squared value of simple regressions between measured and estimated Erm.

\begin{tabular}{|c|c|c|c|c|c|}
\hline \multicolumn{2}{|l|}{ Author } & $\begin{array}{l}\text { Used } \\
\text { Parameters }\end{array}$ & $\begin{array}{l}\mathrm{R}^{2} \\
\text { Bakhtiari }\end{array}$ & $\begin{array}{ll}- & \mathbf{R}^{2} \\
& \text { Khersan } \\
\end{array}$ & $\begin{array}{ll}- & \text { All } \\
& \text { Data }\end{array}$ \\
\hline \multicolumn{2}{|l|}{ Zhang[14] } & RQD, Ei & 0.40 & 0.45 & 0.09 \\
\hline \multicolumn{2}{|l|}{ Hoek et al. $[6]$} & RMR, UCS & 0.70 & 0.65 & 0.66 \\
\hline \multicolumn{2}{|l|}{ Sonmez et al. [7] } & RMR, Ei & 0.66 & 0.58 & 0.28 \\
\hline \multicolumn{2}{|l|}{ Nejati et al. [1] } & RMR Parameters & 0.61 & 0.72 & 0.72 \\
\hline \multicolumn{2}{|l|}{ Barton $[9]$} & Q, UCS & 0.57 & 0.66 & 0.66 \\
\hline \multicolumn{2}{|l|}{ Palmstrom[13] } & RMi & 0.62 & 0.70 & 0.65 \\
\hline \multicolumn{2}{|l|}{ Hoek et al. [6] } & GSI, UCS, D & 0.66 & 0.71 & 0.64 \\
\hline \multicolumn{6}{|l|}{$\begin{array}{l}\text { Hoek } \\
\text { Diederichs[10] }\end{array}$} \\
\hline \multicolumn{2}{|l|}{ Sonmez et al.[11] } & GSI, Ei & 0.62 & 0.48 & 0.00002 \\
\hline \multicolumn{2}{|l|}{ Carvalho [12] } & GSI, Ei & 0.63 & 0.50 & 0.01 \\
\hline \multirow[t]{2}{*}{ Shen et al. [17] } & 1 & RMR & 0.69 & 0.69 & 0.77 \\
\hline & 2 & RMR, Ei & 0.66 & 0.58 & 0.28 \\
\hline \multirow[t]{2}{*}{ Beiki et al. [18] } & 1 & GSI, UCS & 0.66 & 0.72 & 0.67 \\
\hline & 2 & GSI, UCS, RQD & 0.61 & 0.7 & 0.62 \\
\hline \multicolumn{2}{|l|}{ Kayabasi et al.[15] } & RQD, Ei, WD & 0.53 & 0.52 & 0.007 \\
\hline \multicolumn{2}{|c|}{ Gokceoglu et al.[16] } & $\begin{array}{l}\text { RQD, Ei,UCS, } \\
\text { WD }\end{array}$ & 0.24 & 0.69 & 0.05 \\
\hline \multicolumn{2}{|c|}{$\begin{array}{l}\text { Lowson \& Bieniawski } \\
{[19]}\end{array}$} & RMR, Ei & 0.52 & 0.68 & 0.49 \\
\hline
\end{tabular}

As seen in figures 8, 9, and 10 and Table 6, some equations were proven not to be acceptable because of the major differences in their estimation and our test results. The predicted values of these equations were either overestimations or underestimations of the actual value. Further some of comparisons had a very low overall R-squared. Due to lower $\mathrm{E}_{\mathrm{i}}$ value at Khersan II dam site, the calculated $\mathrm{E}_{\mathrm{rm}}$ values from the equations using $\mathrm{E}_{\mathrm{i}}$ were rather underestimations when compared to Bakhtiari dam site, despite both of the sites having an overall high R-squared (see figures 11, 12, and 13). 


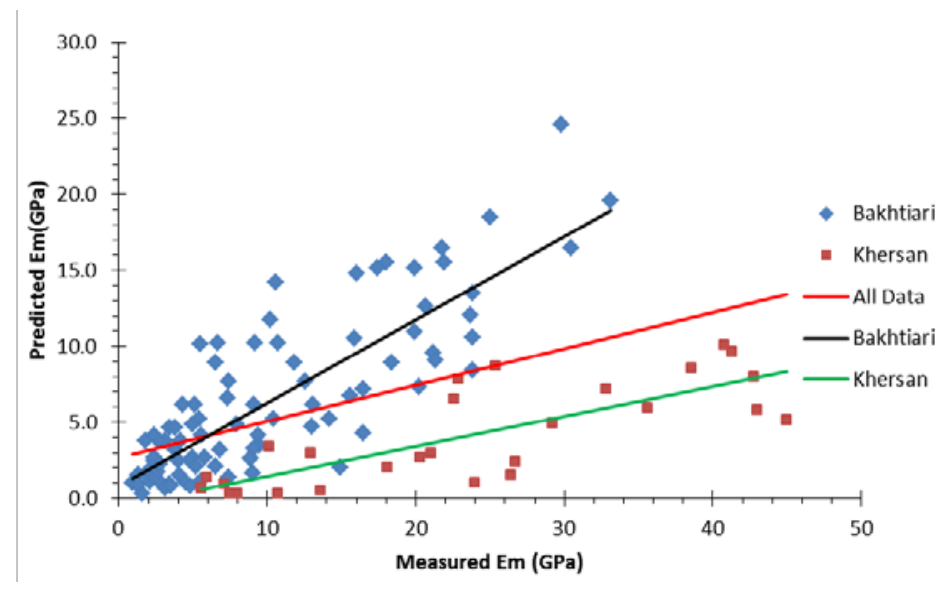

Figure 11. Estimated $\mathrm{E}_{\mathrm{rm}}$ values by $\operatorname{Shen}(2)$ [17] equation in comparison with in situ data.

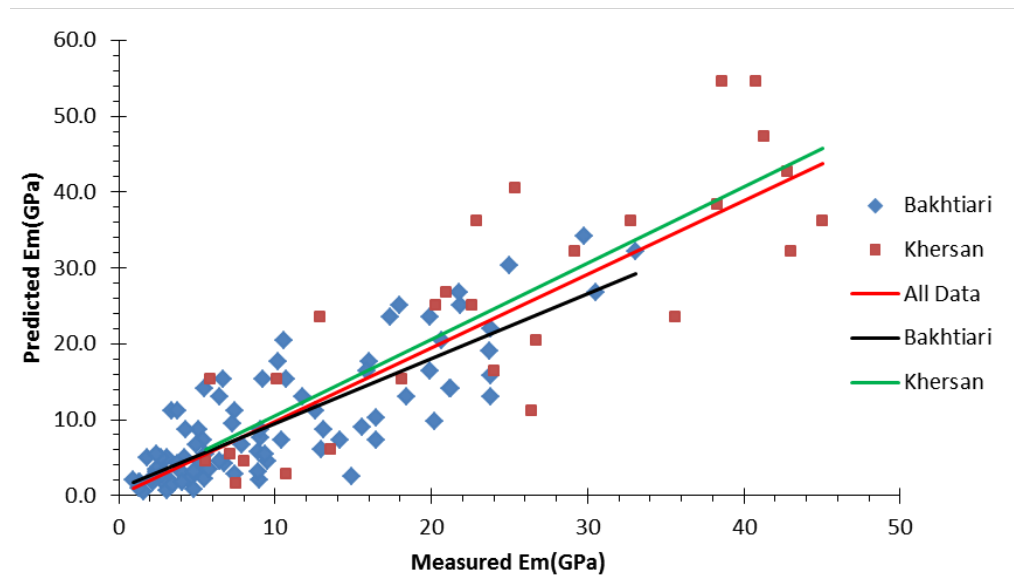

Figure 12. $\mathrm{E}_{\mathrm{rm}}$ value estimated from Shen(1) [17] equation compared with in situ data.

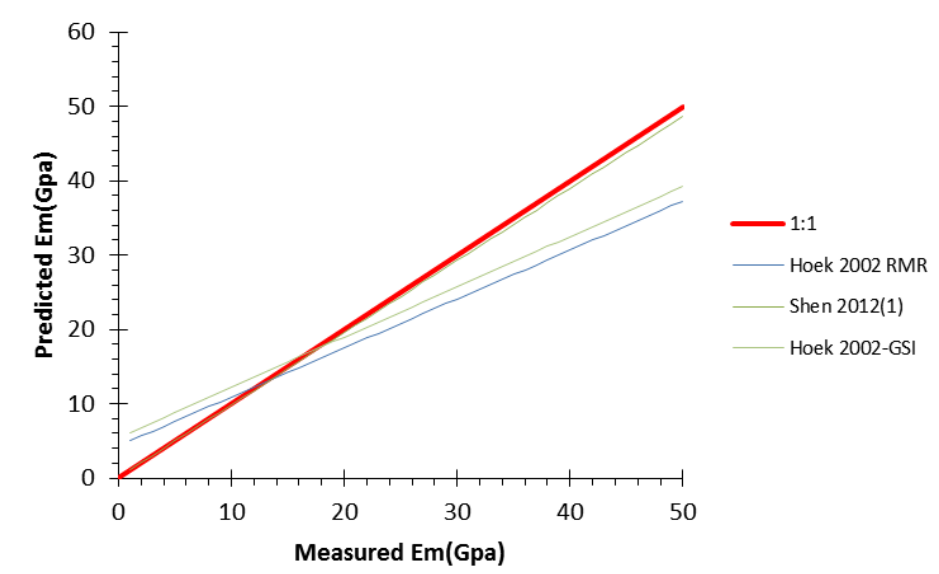

Figure 13. Best fit of selected equations between predicted and in situ data. 


\section{Conclusions}

The correlation between in situ tests data with the predicted value by the classification systems indicates that all of the mentioned classification systems have an approximately similar precision, except RQD system that had presented a lower R-squared value. Also, based on the comparison of the overall R-squared value for both sites, the RMR system presents the best estimation. Moreover, the empirical equations which use $\mathrm{E}_{\mathrm{i}}$ as an input parameter do not provide acceptable results. This imperfection is due to the fact that in high quality rock mass with low $\mathrm{E}_{\mathrm{i}}$, the $\mathrm{E}_{\mathrm{rm}}$ is underestimated. Therefore, the results will be scattered when $\mathrm{E}_{\mathrm{rm}}$ of two rock masses groups with different value of $\mathrm{E}_{\mathrm{i}}$ get estimated together.

Based on these results, the estimations of $\mathrm{E}_{\mathrm{rm}}$ using RMR and GSI classification systems have presented better results than RQD, Q, and RMi systems. Among all the equations related to RMR, Hoek (2002) and Shen (2012) equations have performed the best. It is apparent that Hoek (2002) equation has predicted more acceptable results than other equations with regard to GSI. Further similar experiments at a variety of sites and different compositions are required to further validate our results.

\section{References}

1. Nejati, H.R., et al., On the use of the RMR system for estimation of rock mass deformation modulus. Bulletin of Engineering Geology and Environment, 2014. 73(2): p. 531-540.

2. Bieniawski, Z.T., Determining rock mass deformability: experience from case histories. International Journal of Rock Mechanic Mining Sciences \& Geomechanic, 1978. 15: p. 237-247.

3. Serafim, J.L. and J.P. Pereira. Consideration of the geomechanical classification of Bieniawski. in the International Symposium on Engineering Geology and Underground Construction. 1983. Lisbon, Portugal.

4. Nicholson, G.A. and Z.T. Bieniawski, A nonlinear deformation modulus based on rock mass classification. International Journal of mining ang geological engineering, 1990. 8: p. 181-202.

5. Read, S.A.L., N.D. Perrin, and L.R. Richards. Applicability of the Hoek-Brown failure criterion to New Zealand greywacke rocks. in 9th International Congress on Rock Mechanics. 1999. Paris, France.

6. Hoek, E., C.T. Carranza-Torres, and B. Corkum. Hoek- Brown failure criterion- 2002 edition. in North American Rock Mechanicss Society Meeting. 2002. Torento, Canada.

7. Sonmez, H., et al., Estimation of rock modulus: For intact rocks with an artificial neural network and for rock masses with a new empirical equation. International Journal of Rock Mechanics and Mining Sciences, 2006. 43: p. 224-235.

8. Barton, N. Application of Q-system, index tests to estimate shear strength and deformability of rock masses. in the International Symposium on Engineering Geology and Underground Construction. 1983. Lisbon, Portugal.

9. Barton, N., Some new Q-value correlations to assist in site characterisation and tunnel design. International Journal of Rock Mechanics and Mining Sciences, 2002. 39: p. 185-216.

10.Hoek, E. and M.S. Diederichs, Empirical estimation of rock mass modulus. International Journal of Rock Mechanics and Mining Sciences, 2006. 43: p. 203-215.

11.Sonmez, H., C. Gokceoglu, and R. Ulusay, Indirect determination of the modulus of deformation of rock masses based on the GSI system. International Journal of Rock Mechanics and Mining Sciences, 2004. 41: p. 849-857.

12.Carvalho, J., Estimation of rock mass modulus. Personal comminucation, 2004.

13.Palmstrom, A., RMi - a rock mass characterization system for rock engineering purposes. 1995, University of Oslo: Oslo. p. 381.

14.Zhang, L. and H.H. Einstein, Using RQD to estimate the deformation modulus of rock masses. International Journal of Rock Mechanics and Mining Sciences, 2004. 41: p. 337-341.

15.Kayabasi, A., C. Gokceoglu, and M. Ercanoglu, Estimating the deformation modulus of rock masses: a comparative study. International Journal of Rock Mechanics and Mining Sciences 2003. 40: p. 55-63.

16.Gokceoglu, C., H. Sonmez, and A. Kayabasi, Predicting the deformation moduli of rock masses. International Journal of Rock Mechanics and Mining Sciences, 2003. 40: p. 701-710.

17.Shen, J., M. Karakus, and C. Xu, A comparative study for empirical equations in estimating deformation modulus of rock masses. Tunnelling and Underground Space Technology, 2012. 32: p. 245-250. 
18.Beiki, M., A. Bashari, and A. Majdi, Genetic programming approach for estimating the deformation modulus of rock mass using sensitivity analysis by neural network International Journal of Rock Mechanics and Mining Sciences, 2010. 47: p. 1091-1103.

19.Lowson, A.R. and Z.T. Bieniawski, Critical Assessment of RMR based Tunnel Design Practices: a Practical Engineer's Approach, in RAPID EXCAVATION \& TUNNELING. 2013: Washington, DC. p. 180-189.

20.Palmstrom, A. and R. Singh, The deformation modulus of rock masses - comparisons between in situ tests and indirect estimates. Tunnelling and Underground Space Technology, 2001. 16(3): p. 115-131.

21.ISRM, Suggested methods for determining in-situ deformability of rock- Part I: Suggested method for deformability determination using a plate test. International Journal of Rock Mechanics Mining Sciences and Geomechanics, 1979. 16: p. 197-202.

22.ASTM, Standard Test Method for Determining the In Situ Modulus of Deformation of Rock Mass Using the Rigid Plate Loading Method. 2008: West Conshohocken, United States.

23.Deere, D.U., Rock quality designation(RQD) after twenty years 1989, U.S. Army crops of engineering. p. 67.

24.Bieniawski, Z.T., Engineering Rock Mass Classifications. 1989, New York: Wiley. 215.

25.Barton, N., R. Lien, and J. Lunde, Engineering classification of rock masses for the design of tunnel support. Rock Mechanics, 1974. 6: p. 189-236.

26.Hoek, E., P.K. Kaiser, and W.F. Bawden, Support of underground excavation in hard rock. 1995, Rotterdam: Balkema.

27.Marinos, P. and E. Hoek. GSI: A geological friendly tool for rock mass strength estimation. in the International Confrence on Geotechnical and Geological Engineering. 2000. Melbourne Australia.

28.Marinos, V., P. Marinos, and E. Hoek, The geological strength index: applications and limitations. Bulltin of Engineering Geology and Environment, 2005. 64: p. 55-65.

29.Hoek, E., T.G. Carter, and M.S. Diederichs. Quantification of the Geological Strength Index Chart in 47th U.S. Rock Mechanics/Geomechanics Symposium. 2013. San Francisco, California American Rock Mechanics Association.

30.Russo, G., A new rational method for calculating the GSI. Tunnelling and Underground Space Technology, 2009. 24(1): p. 103-111.

31.Cai, M., et al., Determination of residual strength parameters of jointed rock masses using the GSI system. International Journal of Rock Mechanics and Mining Sciences, 2007. 44: p. 247-265. 